JPPIPA 7(1) (2021)

\title{
Development of Natural Science Learning Tools with Guided Inquiry Model Assisted by Real Media to Improve Students' Scientific Creativity and Science Process Skills
}

\author{
Aris Doyan ${ }^{1.2 *}$, Susilawati1 ${ }^{1,2}$, Adi Hardiyansyah ${ }^{1}$ \\ ${ }^{1}$ Master of Science Education Study Program, Postgraduate Program, Mataram University, Lombok, West Nusa tenggara, Indonesia \\ 2Physics Education Study Program, FKIP, Mataram University, Lombok, West Nusatenggara, Indonesia
}

DOI: $10.29303 /$ ippipa.v7i1.485

\section{Article Info}

Received: September 28th, 2020

Revised: November 17th, 2020

Accepted: November 23th 2020

\begin{abstract}
This study aims to develop science learning tools with guided inquiry models assisted by real media to improve scientific creativity and science process skills of grade VIII students at SMP IT Putra and SMP IT Putri Mataram on light and optical equipment. The development of this tool adopts the development of Dick and Carey. The resulting products are in the form of learning tools in the form of syllabus, lesson plans, LKPD, scientific creativity instruments and science process skills. Before being used, the device was validated by four expert validators and the result was that the device developed was suitable for use in learning. To test the effectiveness of the device, scientific creativity and scientific process skills were tested. The results of the scientific creativity test obtained an average N-Gain of 0.4 . This shows that the device developed is quite effective in increasing the scientific creativity of students in the two schools being the subject. The second effectiveness test is the science process skills test. The average N-Gain value obtained was 0.7 , this indicates that the learning device developed with a guided inquiry model assisted by real media is very effective in improving students' science process skills
\end{abstract}

Keywords: Guided Inquiry; Real Media; Scientific Creativity; Science Process Skills.

Citation: Doyan, A., Susilawati, S., \& Hardiyansyah, H. (2020). Development of Natural Science Learning Tools with Guided Inquiry Model Assisted by Real Media to Improve Students' Scientific Creativity and Science Process Skills. Jurnal Penelitian Pendidikan IPA, 7(1), 15-20. doi:https:// doi.org/10.29303/jppipa.v7i1.485.

\section{Introduction}

The development of science and technology continues to develop rapidly so that it demands the availability of quality human resources. Various tasks and jobs in the globalization era require adequate knowledge and skills. One of the efforts to form a quality young generation is to improve the quality and quality of education. The creation of good quality education is by providing quality teachers in terms of planning and implementing learning and evaluating learning outcomes (Sugihartono, 2013).

Education in Indonesia follows the rules of Law No. 20 of 2003 concerning the National Education
System explains that education is a plan to develop the potential and skills of students both in the form of spiritual, social and intelligence attitudes needed in the life of the nation and state. The skills possessed are of course greatly influenced by learning in schools (Law No. 20 of 2003). Learning objectives are bills that must be achieved after carrying out a learning process that includes cognitive, effective, and psychomotor (Slameto, 2015).

The success of educational goals is largely determined by the curriculum that is held as a reference in learning activities. In 2013, a new curriculum emerged as a development from the previous curriculum. The curriculum development guidelines 
compiled by the National Education Standards Agency (BSNP) have the objective of one of which is to provide knowledge and skills of students. The big goal of developing this curriculum is to integrate knowledge with the strengthening of attitudes and skills that students must have in order to become productive, innovative, creative, and affective humans (Mulyasa, 2013).

Natural Science (IPA) is one of the subjects that gives students the opportunity to train the skills of students to become creative and critical thinking people (Aryani, et al, 2019).

Koballa and Chiappetta (2010) in their book Science Instruction in the Middle and Secondary Schools defines science lessons as a mindset, a way of doing research, and a body of knowledge. The essence of science is not only marked by factual data, but is marked by the existence of a scientific method which is implemented through a series of scientific activities and scientific attitudes.

Science learning requires educators to provide opportunities for students to be directly involved in developing competencies so that students are able to understand the state of the environment scientifically (Afful, et al, 2020). The purpose of science education is to guide students in understanding the concepts of nature and their relationships and to be able to solve problems they encounter in their daily lives (Arici, et al 2009). For this reason, Zidny and Eilks (2020) state that science lessons not only make students memorize and know about science concepts, but also train students to understand problems, analyze, and find solutions to problems based on their knowledge and thinking skills.

Based on scientific research conducted by Lee and Erdogan in 2007, it was found that a lack of interest in learning science among students occurred in those who were at the high school level. One of the internal factors that affect student learning outcomes is low interest in learning. Nurhaeni's research results (2011) indicate that the cause of the lack of interest in learning science is because the learning process is carried out by lecturing methods and giving questions regularly. They assume that science learning only talks about boring formulas, even though at their age they have real thinking characteristics so that students have difficulty learning abstract concepts.

Amalia, et al (2012) stated that to overcome the lack of interest of students in learning science, a fun learning model is needed and students are directly involved in the learning. One learning model that is able to increase the creativity and science process skills of students is the guided inquiry learning model. Guided inkuri is an approach to gaining knowledge by asking, observing, investigating, analyzing, and evaluating. Jacobsen and David (2009) quoted by
Nurfausiah and Suhardiman (2016) state that the guided inquiry learning model is a learning model designed to teach concepts and relationships between material concepts, so that students have creativity and skills in solving a problem.

In addition to the learning model, the learning media used in learning activities also contribute to attracting students' interest in learning. One of the media that is able to attract students' interest is the use of real media that can be seen and felt directly by students so as to increase curiosity, understanding and learning attractiveness (Tanrere, 2008). Onasanya (2004) states that the use of real media in learning can help teachers communicate effectively. Arsyad (2011) states that the use of real media in learning can increase students' interest in learning and can generate motivation and influence the learning psychology of students.

Technological developments have touched various groups including the world of education. One of them is the development of communication technology. Today's smartphones are developing very fast with various sophisticated features, one of which is a webcam application. On a smartphone this application functions to connect media files on the smartphone to the projection screen, so that what is captured using a smartphone can be seen clearly by students (Barone, et al, 2016).

The results of research by Dumitru, et al (2018) state that the use of smartphone media in the learning process greatly affects student learning outcomes. Kurniawan (2013) states that the use of media in learning can improve students' creativity, because when learning activities take place, students are directly involved in learning so that they generate creative ideas in solving problems. Hermanyah, et al (2015) state that the use of learning media is effective in bringing up creative thinking of students so that in solving problems students have many ways to solve them.

Based on the background described, research was carried out on the development of guided inquiry learning models assisted by real media to improve scientific creativity and science process skills of junior high school students.

\section{Method}

This research includes development research that develops real media assisted learning tools using the Dick and Carey development model. It has 10 stages of development: (1) Formulating specific learning objectives; (2) Student and Context Analysis; (3) Instructional Analysis; (4) Identification of Learning 
Objectives; (5) Developing Tools or Instruments; (6) Develop Learning Strategies; (7) Use of teaching materials; (8) Designing and implementing formative evaluations; (9) Revising the draft learning program; (10) Designing and developing summative evaluation.

The initial product developed in this study was in the form of learning tools assisted by real media, in the form of syllabus, lesson plans, student worksheet, conceptual understanding evaluation instruments, and science process skills. After the development process is carried out, then it is validated by three expert validators, in order to obtain validity data. The suggestions given by the validators are then used as a reference for improving the learning tools developed.

The validation data obtained were then analyzed using the percentage of components based on the Likert scale in Table 1.

Table 1. Scoring Questionnaire Instruments

\begin{tabular}{ll}
\hline Answer & Score \\
\hline Very Good & 5 \\
Good & 4 \\
Enough & 3 \\
Less & 2 \\
Very Less & 1 \\
\hline
\end{tabular}

Furthermore, the validation score is calculated using the following equation.

$$
P_{(k)}=\frac{s}{N} \times 100 \%
$$

Where:

$\mathrm{P}_{(\mathrm{k})}=$ Percentage of components

$\mathrm{S}=$ The total score of the research results component

$\mathrm{N}=$ Maximum number of scores

The percentages that have been obtained are then transformed into intervals as in Table 2.

Table 2. Percentage ranges and qualitative criteria

\begin{tabular}{ll}
\hline Percentage & Criteria \\
\hline $85 \%-100 \%$ & Very Good \\
$69 \%-84 \%$ & Good \\
$53 \%-68 \%$ & Enough \\
$37 \%-52 \%$ & Less \\
$20-36 \%$ & Very Less \\
\hline
\end{tabular}

(Sugiyono, 2017)

To see the increase in students' understanding of science process concepts and skills, the N-Gain equation is used as follows (Sugiyono, 2017).

$$
\mathrm{N} \text {-gain }=\frac{\text { Spost }- \text { Spre }}{\text { Smax }- \text { Spre }} \times 100 \%
$$

The criteria for the N-Gain score can be seen in Table 3 .
Table 3. Criteria for Gain Score

\begin{tabular}{ll}
\hline Classification & Category \\
\hline $0,7<\boldsymbol{g} \leq 1$ & High \\
$0,3<\boldsymbol{g} \leq 0,7$ & Middle \\
$\boldsymbol{g} \leq 0,3$ & Low \\
\hline
\end{tabular}

\section{Results and Discussion}

This research was conducted in two schools, namely SMP IT Putra Mataram and SMP IT Putri Mataram. This study used two classes VIII each from each institution, namely class VIII A and class VIII B. The data obtained in this study were the results of the validation of learning devices and the results of evaluation of conceptual understanding and scientific skills for the material of Light and Optical Devices. For the results of evaluating the understanding of science concepts and skills, two tests were carried out, namely the pre-test which was carried out before the students took the learning and the post-test after the students participated in the learning. The results of the analysis of the validity test of the device can be seen in Table 4 .

Table 4 . The results of the learning device validity test

\begin{tabular}{llll} 
No. & $\begin{array}{l}\text { Aspects assessed } \\
(\%)\end{array}$ & $\begin{array}{l}\text { Values } \\
(\%)\end{array}$ & Description \\
\hline 1. & Syllabus & 92.44 & Very Appropriate \\
2. & Lesson Plan & 92.59 & Very Appropriate \\
3. Worksheet & 96.00 & Very Appropriate \\
4. & $\begin{array}{l}\text { Concept Mastery } \\
\text { Assessment }\end{array}$ & 85.71 & Very Appropriate \\
5. $\quad \begin{array}{l}\text { Instrument for } \\
\text { Assessment of }\end{array}$ & 85.71 & \\
& $\begin{array}{l}\text { Scientific Creativity } \\
\text { Average }\end{array}$ & 89.14 & Very Appropriate \\
\end{tabular}

Based on Table 4, it can be seen that the learning device developed after being validated by an expert validator gets the predicate very suitable for use. This means that this learning device can be used in learning. Rajabi, Ekohariadi, and Buditjahjanto (2015) state that learning tools are said to be feasible if the indicators and learning objectives have consistency to be achieved. Meanwhile, Mustami and Irwansyah (2015), Kartini et al (2019) state that learning tools are said to be feasible if they are based on strong theories and have consistency with the learning objectives to be achieved.

Learning tools that have been developed are then used in learning with the aim of measuring the creativity and science process skills of students. The benchmark for measuring the effectiveness of this learning device is by looking at changes in the pretest and posttest scores on the two components of scientific creativity and science process skills.

The test of the effectiveness of the guided inquiry model learning device assisted by real media uses tests 
of scientific creativity and science process skills. The results of scientific creativity tests can be seen in Figure 1.

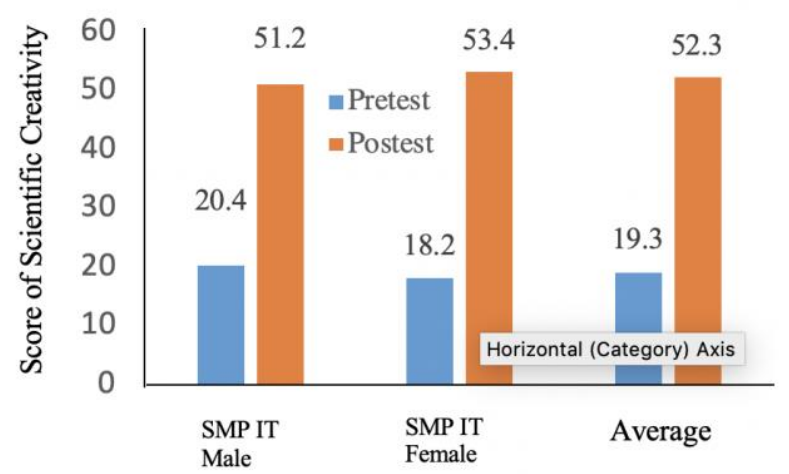

Figure 1. Graph of Pre-Test, Post-Test and Average Score of Scientific Creativity

Figure 1 above shows that the device developed effectively increases the scientific creativity of students. This can be seen from the increase in the average pre-test and post-test scores of students in the two schools as shown in the picture above. This increase is also evidenced by the results of calculations using the N-Gain equation as shown in the N-Gain graph which can be seen in Figure 2.

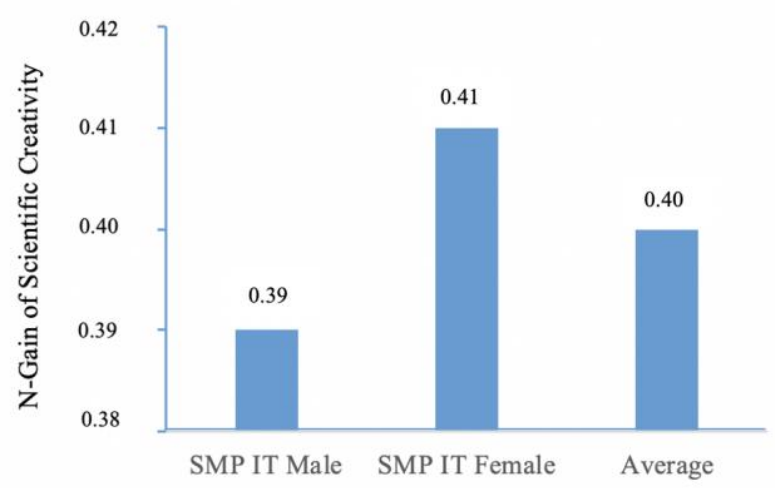

Figure 2. Graph of N-Gain Value of Scientific Creativity

Figure 2 shows that the scientific creativity of students in the two schools that were the research subjects was in the medium category, because the $\mathrm{N}$ Gain scores obtained were 0.39 and 0.41 . The score is in the range 0.3 to 0.7 according to the N-Gain Table, this range is in the medium criteria.

In 2015 Birgili stated that creativity is part of creative thinking, namely by arranging individual cognitive activities according to certain objects, problems, and conditions. In addition, creativity is also assessed from the way individuals assess problems based on imagination, intelligence, insight, and ideas (Young and Balli, 2014). Hu and Adey (2010) state that when an individual is able to create an original product with intellectual properties designed by utilizing certain information, it can be said to be scientific creativity. Barros (2010) and Nakano, et al. (2015) stated that the creativity of students is closely related to children's intelligence, that is, they are able to reveal ideas or ideas that have not been thought of by others.

The next device effectiveness test is the science process skills test. The test results can be seen in Figure 3 . |

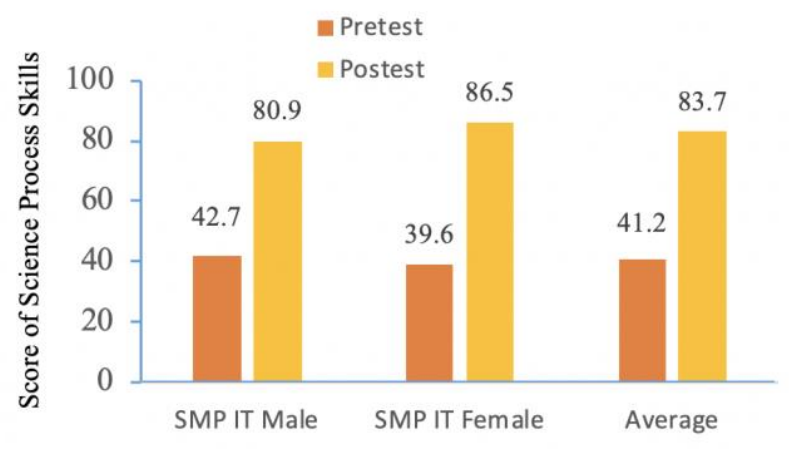

Figure 3. Graph of Pre-Test, Post-Test and Average Science Process Skills

Figure 3 shows a significant change between the pretest and posttest scores on the science process skills test. This shows that the learning tools developed are effective in improving science process skills. This increase is also evidenced by the results of calculations using the N-Gain equation as shown in the N-Gain graph which can be seen in Figure 4 .

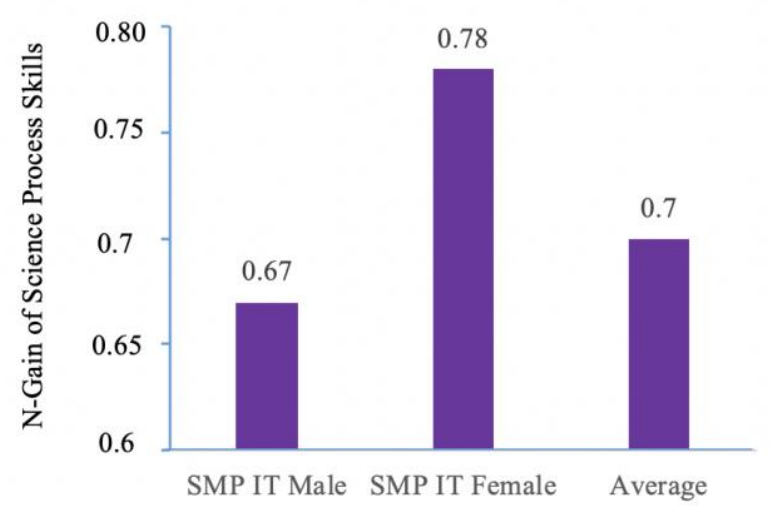

Figure 4. Graph of N-Gain Value of Science Process Skills

The average value of the N-Gain test on science process skills above is at 0.7 . Based on the N-Gain value distribution table, the effectiveness of the device being developed is very high.

The results of the science process skills test have increased influenced by several steps in the guided inquiry learning model activities used. Pujiningrum and Admoko (2017) state that students who carry out learning by observing directly, making observations, are able to solve and formulate their own problems so 
that they are able to solve the problems at hand. Trianto (2015) states that the guided inquiry learning model is able to guide students to take up slogical, systematic, and critical thinking maximally.

Doyan et al (2020), Hu and Adey (2010) and Dewi, (2017) added that students who have the ability to answer with scientific creativity are students who have original ideas. For example, when presented with a problem that asks students to write down as many uses of the lens as they know, they straightforwardly and smoothly write down some of the benefits of the lens that they know with reasons and benefits that are of course scientific.

\section{Conclusion}

The conclusions that can be obtained based on the objectives of the research carried out are that: The learning tools developed with a guided inquiry model assisted by real media are effective in increasing scientific creativity with an average $\mathrm{N}$-Gain value obtained by 0.4 , and effectively improving science processing skills with an average value -The N-Gain average obtained was 0.7 . This means that the increase in value is in the medium and high categories.

\section{References}

Amalia, S., Rusilowati, A., \& Supriyadi. (2011). Penerapan Physics Communication Games dengan Pendekatan SETS untuk meningkatkan Pemahaman Kebencanaan dan Minat Belajar Sains Fisika Siswa SMP. Jurnal Pendidikan Fisika Indonesia, 7:101105.

Arici, F., Yildirim, P., Caliklar, Ş., \& Yilmaz, R. M. (2019). Research trends in the use of augmented reality in science education: Content and bibliometric mapping analysis. Computers \& Education, 103647.

Afful, A. M., Hamilton, M., \& Kootsookos, A. (2020). Towards space science education: A study of students' perceptions of the role and value of a space science program. Acta Astronautica, 167, 351-359.

Arsyad, A. (2011). Media Pembelajaran. Jakarta: PT Raja Grafindo Persada.

Aryani, P.S., Akhlis, I., \& Subali, B. (2013). Penerapan Model Pembelajaran Inkuiri Terbimbing Berbentuk Augmented Reality pada Peserta Didik untuk Meningkatkan Minat dan Pemahaman Konsep IPA. Unnes Physics Education Journal Terakreditasi SINTA 3 UPEJ 8 (2) (2019).

Barone, V., Verdini, F., Burattini, L., Di Nardo, F., \& Fioretti, S. (2016). A markerless system based on smartphones and webcam for the measure of step length, width and duration on treadmill. Computer Methods and Programs in Biomedicine, 125, 37-45.

Barros, D. P., Primi, R., Miguel, F. K., Almeida, L., dan Oliveira, E.P. (2010). Metaphor Creation: A Measure of Creativity or Intelligence?. European Journal of Education and Psychology, 3(1), 103-115

Birgili, B. (2015). Creative and Critical Thinking Skills in Problem-based Learning Environments. Journal of Gifted Education and Creativity, 2(2), 7180

Dewi, V. P., Doyan, A., Soeprianto, H. (2017). Pengaruh Model Penemuan Terbimbing Terhadap Keterampilan Proses Sains Ditinjau Dari Sikap Ilmiah Pada Pembelajaran IPA, Jurnal Penelitian Pendidikan IPA, 3(1), 60-67, doi: 10.29303/jppipa.v3i1.102

Doyan, A., Jufri, A. W., Susilawati, Hardiyansyah, A., Auliya, K., Hakim, S., Muliyadi, L, (2020), Development of Learning Media of Microscope Portable Auto Design to Increase Student's Problem- Solving Ability in Light and Optical Tools Topic, Advances in Social Science, Education and Humanities Research, Atlantis Press, (438), 300-302.

Dumitru, A. I., Girbacia, T., Boboc, R. G., Postelnicu, C.C., \& Mogan, G.-L. (2018). Effects of smartphone based advanced driver assistance system on distracted driving behavior: A simulator study. Computers in Human Behavior, 83, 1-7.

Hermansyah, Gunawan, dan Heryanti, Lovi. 2015. Pengaruh Penggunaan Laboratorium Virtual Terhadap Penguasaan Konsep Dan Kemampuan Berpikir Kreatif Siswa Pada Materi Getaran Dan Gelombang. Jurnal Pendidikan Fisika dan Teknologi (ISSN. 2407-6902) Volume I No 2, April 2015.

Hu, W. dan Adey, P. (2010). A Scientific Creativity Test for Secondary School Students. International Journal of Science Education.

Kartini, Doyan, A., Kosim, Susilawati, Khasanah, B.U., Hakim, S., Muliyadi, L., (2019). Analysis of Validation Development Learning Model Attainment Concept to Improve Critical Thinking Skills and Student Learning Outcomes, Jurnal Penelitian Pendidikan IPA, 5(2), 185-188, doi: 10.29303/jppipa.v5i2.262

Koballa \& Chiapetta. (2010). Science Instruction in the Middle and Secondary Schools. Pearson: USA.

Kurniawan, A, D. 2013.metode inkuiri terbimbing dalam pembuatan media pembelajaran biologi untuk meningkatkan pemahaman konsep dan kreativitas siswa smp. Jurnal Pendidikan IPA Indonesia. JPII 2 (1) (2013) 8-11. 
Lee, M. K. dan I. Erdogan. (2007). The Effect of Science Technology Society on Students' Attitudes Toward Science and Certain Aspects of Creativity. International Journal of Science Education.

Mulyasa. (2013). Pengembangan dan Implementasi Kurikulum 2013. Bandung: PT Remaja Rosdakarya.

Mustami, M.K. dan Irwansyah. M. (2015). Pengembangan Lembar Kerja Peserta Didik (LKPD) Berorientasi Pendekatan Saintifik Pada Mata Pelajaran Biologi SMA, Lentera Pendidikan 18 (2).

Nakano, T. D. C., Wechsler, S.M., Campos, C.R., dan Milian, Q.G. (2015). Intelligence and Creativity: Relationships and their Implications for Positive Psychology. Criatividade e inteligência na Psicologia Positiva.

Nurfausiah \& Suhardiman. (2016). Pengaruh Model Pembelajaran Inkuiri Terbimbing terhadap Hasil Belajar. Jurnal Pendidikan Fisika, 4 (1).

Nurhaeni, Y. (2011). Meningkatkan Pemahaman Siswa pada Konsep Listrik Melalui Pembelajaran Kooperatif Tipe Jigsaw Pada Siswa Kelas IX SMPN 43 Bandung. Jurnal Penelitian Pendidikan, 12 (1).

Onasanya, S. A. (2004). Selection And Utilization Of Instructional Media For Effective Practice Teaching. Institute Journal of Studies in Education, $2(1)$.

Pujiningrum, L., \&Admoko, S. (2017). Penerapan Model Pembelajaran Inkuiri Terbimbing untuk Meningkatkan Keterampilan Proses Sains Materi Getaran Harmonik di MAN Sidoarjo. Jurnal Inovasi Pendidikan Fisika (JIPF). 6(3): 203208

Rajabi, M., Ekohariadi, dan Buditjahjanto, A. (2015). Pengembangan Perangkat Pembelajaran Instalasi Sistem Operasi dengan Model Pembelajaran Berbasis Proyek. Jurnal Pendidikan Vokasi : Teori dan Praktek 3(1): 48-49.

Slameto. (2015). Belajar dan factor-faktor yang mempengaruhinya. Jakarta: Rineka Cipta.

Sugihartono. (2013). Psikologi Pendidikan. Yogyakarta: UNY Press.

Tanrere,M. (2008). Enviromental Problem Solving in Learning Chemistry for High School Students. Jurnal of Applied Sciences in Enviromental anitation 3(1).

Trianto. (2015). Mendesain Model Pembelajaran Inovatif, Progresif, dan Kontekstual. Jakarta: Kencana.

Young, M. H. dan Balli, S. J. (2014). Gifted and talented education: student and parent perspectives. Gifted Child Today, 37(4), 236-246.

Zidny, R., \& Eilks, I. (2020). Integrating perspectives from indigenous knowledge and Western science in secondary and higher chemistry learning to contribute to sustainability education. Sustainable Chemistry and Pharmacy, $16,100229$. 